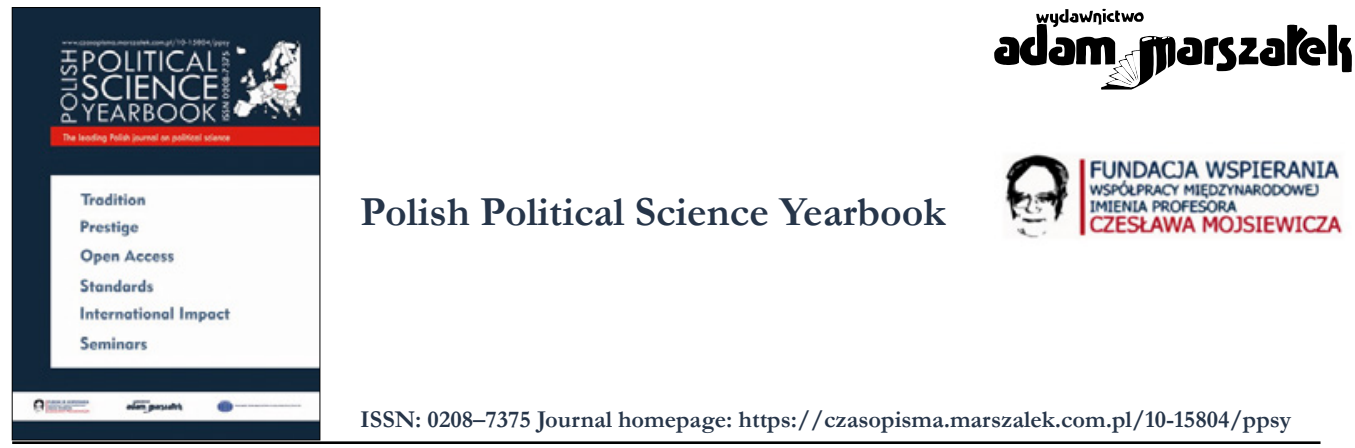

\title{
Age Discrimination (Aspects and Manifestations) in the Perception of Active Seniors
}

\section{Michał Kubiak}

ORCID: 0000-0002-4231-8071

To cite this article please include the following information:

- Journal title: Polish Political Science Yearbook

- Volume number: 50

- Year of publication: 2021

- Published ahead-of-print

Example styles:

[APA Style]: Kubiak, M. (2021). Age Discrimination (Aspects and Manifestations) in the Perception of Active Seniors. Polish Political Science Yearbook, 50 (issue number), pages. https://doi. org/10.15804/ppsy202142

[Chicago Style]: Michał Kubiak, “Age Discrimination (Aspects and Manifestations) in the Perception of Active Seniors" Polish Political Science Yearbook 50, no. [issue number] (2021).

To link to this article: https://doi.org/10.15804/ppsy202142

Published ahead-of-print

\begin{tabular}{l} 
Final submission: 12 July 2021 \\
\hline Published online: 19 July 2021 \\
\hline Printed issue: 2021 \\
Submit your article to PPSY
\end{tabular}




\title{
Michał Kubiak
}

University of Gdańsk (Poland)

ORCID: 0000-0002-4231-8071

e-mail: michal.kubiak@ug.edu.pl

\section{Age Discrimination (Aspects and Manifestations) in the Perception of Active Seniors}

\begin{abstract}
Among many demographic changes, one of the most evident now is the aging of the population, the consequences of which are increasingly leaving a mark on the directions of social policy. In connection with the aging of the population and positive aspects, manifestations of ageism, based on stereotypes and negative attitudes toward older people, are also more and more noticeable. Sometimes, these are discriminatory practices against older people encountered in the health sector, the labor market, public offices, and others. The research presented in the article aimed to identify age discrimination and its manifestations among older people. The purposive sampling technique was used to choose the research sample - the assumption was to examine active older people related to a large city who get involved and participate in various activities and projects carried out for them by nongovernmental organizations. The method of a diagnostic survey with a questionnaire, which included both closed and open-ended questions, was used in the research. The research was intended to help answer the following questions: do older people notice age discrimination, and have they experienced worse treatment because of their age? How many of the surveyed seniors experienced worse treatment and what forms (most often) did it take, and where did it happen?
\end{abstract}

Keywords: social policy, senior policy, age discrimination, ageism, stereotypes, old age, older people, aging

\section{Introduction}

In Poland, as in other European countries, we are dealing with the demographic aging of the population and changes in the population age structure. The extension of life expectancy, a low fertility rate, and emigration have a major impact on the relatively fast population aging process. At the end of 2018, the population of Poland was 38.4 million people, including over 9 million people aged 60 and more (almost 24.8\%, while in 2010, it was 19.6\%, in 2050, 
it will be over $40 \%$ of the populace). In the subpopulation of older people, the largest group is made up of people aged $60-69$ (about $54.6 \%$ of the total number), followed by people aged $70-79$ (about $27.9 \%$ among older people), and $17.3 \%$ people over 80 years of age (GUS, 2020a, pp. 13-19). In turn, taking into account the criterion of 65 years (as the conventional beginning of old age), in 2018, such people accounted for $17.5 \%$ (GUS, 2019, p. 16) (17.7\% in 2020) (GUS, 2020b, p. 163), while in 2060 there will be $35.6 \%$ of them (according to the UN forecast of 2019).

In the face of the escalating process of the demographic aging of societies, the situation of older people is the subject of many studies and analyses. The very phenomenon of aging has already become one of the most significant challenges of many spheres of social life, including the operation of pension systems, health care, or the labor market, especially in European Union countries. The consequences of the aging of societies will affect not only older people themselves but also younger groups, who will co-finance various types of benefits, including health care and social welfare. The growing share of aging people in society manifests itself almost everywhere (streets, shops, health care facilities, public transport) and is especially visible in large cities. Sometimes, however, we deal with negative attitudes toward older people, perpetuating stereotypes about them, or even discrimination against them.

\section{Sources and Threats of Discrimination on the Grounds of Age}

In common understanding, discrimination (Latin dyskryminatio - differentiation) means more than differentiation itself because it has a negative meaning. The key to discrimination is the statement that it is unfair treatment of people because of their group affiliation, with the emphasis that one can be discriminated against on the grounds of different affiliations: due to sex, health, or appearance, but also because of belonging to a stigmatized subculture or as a result of one's lifestyle and views (it means inappropriate, selective, harmful, unjustified and unfair treatment of individuals because of their group affiliation). From a psychological perspective, discrimination can manifest itself in many ways: direct abuse, refusing to help, verbal and non-verbal behavior, overt evaluation, unfavorable treatment, physical and symbolic violence (Cieślikowska, 2010, p. 108).

Age discrimination consists largely of various forms of stereotypes ascribing negative traits to seniors, which exist in social consciousness and attitudes. Stereotypes defined as a "shortened, simplified and evaluative image of reality functioning in social consciousness" (Mitosek, 1974,p. 12) or as a prejudice, a false, negative judgment about people, not only have an opinion-forming power but also determine behavior toward social groups categorized and perceived through the prism of negative convictions. These simplifications and exaggerations lead to creating a far-from-the-truth image of old age and, consequently, even to discriminatory behavior. According to such a stereotypical image, an older man is associated with infirmity, sickness, inability to lead an independent life, requiring constant help and 
care, which, combined with unproductivity, becomes a burden for family members and the entire society (especially the society of highly developed countries) (Kilian, 2004). It also assumes the perception of older people as a uniform social group.

Discrimination against age can be divided into:

- direct, when a person is treated less favorably than another person is treated or would be treated in a comparable situation solely because of their age;

- indirect, when seemingly neutral conditions, criteria, or practices are applied to all persons, although they particularly affect a specific age group and cannot be objectively explained;

- multiplied when several elements (i.e., age, gender, race, disability, sexual orientation) overlap. In this case, this type of discrimination is experienced by various groups of people (e.g., people with disabilities, homosexuals, ethnic minorities, older women) (Woźniak-Hasik, 2007, p. 3.).

Discrimination against age is often equated with ageism - a term introduced by Robert N. Butler (Butler, 1975), which means a negative, degrading attitude toward older people based on stereotypes and prejudices. Thus, older people are perceived as weaker (both physically and mentally), less attractive, parasitizing social welfare. Ageism is based on stereotypes expressed in language, gestures, jokes, and customs. It exists at home, school, media, hospitals, and nursing homes. It is expressed by children, adolescents, adults, and people from various social strata (Butler, 1969). However, it can also be expressed by older people concerning other seniors.

Generally, discrimination against age refers to the concept of equal rights for an individual. Ageism includes attitudes based on prejudices and stereotypes, resulting from the differentiation of people on the grounds of age (Woźniak-Hasik, 2007).

Bill Bytheway (1995, p. 14) defines ageism as a "set of beliefs, prejudices and stereotypes evolved from the biological diversity of people, which concern the competences and needs of people depending on their chronological age". In its advanced form, ageism is compared to sexism and racism (Palmore \&Manton, 1973). In the case of individual people, ageism may, for example, lead to a loss of self-esteem in old age or a reduction in life requirements and expectations regarding the quality of received medical and rehabilitation services. The generation of older people suffering from ageism may insufficiently express their real needs or create interest groups working to satisfy them (Kilian, 2007).

The proper understanding of the ageism phenomenon depends on noticing all forms and manifestations of inappropriate treatment of older people in the social space (Herman, 2017, p. 160). On the one hand, the sources of ageism are psychological - they result from fears of inevitable old age, disability, faintness, uselessness, and death. On the other hand, they are based on an economy aimed at profit and efficiency, thus marginalizing economically inefficient people.

One of the factors outlining a negative image of old age in highly developed Western societies is the fear of death prevailing in them. In this view, an older person represents old 
age and death, which seem to be synonyms. Therefore, running away from death means escaping from all signs of old age (Traxler, 1980). Consequently, the cult and culture of youth develop mentioned as one of the factors contributing to ageism. The glorification of youth leads to the intensification of activities aimed at preserving or restoring a youthful appearance. As early as the 1980s, Patricia Moore, the author of the research and book Disguised, described her three-year (1979-1982) experience of playing the role (disguised in grey hair, glasses, walking with a cane, etc.) of an older woman in 14 US states and 116 cities. A conclusion drawn from her experiences is that ill-treatment was an almost automatic reaction to her old appearance (Moore \& Conn, 1985).

Two basic forms of ageism can be differentiated depending on the age of the discriminating group: adultism, which is based on aversion toward children and young people (generally all those who are not considered adults), and jeunism (discrimination against older people). It concerns political positions, functions in business and culture, in which alleged greater vitality and physical attractiveness ascribed to youth is more valued than alleged greater morality, life experience, and emotional stability attributed to older people. In extreme cases, jeunism may take the form of gerontophobia, i.e., fear of older people, of contacts with them, but also the dread of the very process of aging, passing away (Dubanik \& Kubacka, 2010).

It is argued that discrimination occurs on three levels: individual (people's behavior), institutional (at the level of a group, organization and institution, and even society, these are patterns of behavior inconsistent with the principles of equality and justice), structural (when several areas of life overlap and mutually reinforce each other in denying equal rights in access to goods - we are talking here about, for example, exclusion, i.e., the impossibility and inability to participate in important aspects of social, economic, political or cultural life, e.g., by people with physical disabilities) (Cieślikowska, 2010, pp. 112-113).

Ageism can manifest itself at the micro, i.e., individual level (thinking, attitudes, and informal interpersonal relations based on personal features and culture of people participating in the contact) or the macro, i.e., institutional and structural level (encompassing the legal, political, social and educational system) (Dubanik \& Kubacka, 2010, p. 137) - e.g., in health care. As Jarosław Derejczyk claims, a manifestation of discriminatory behavior is not mentioning the problems of a patient in advanced age, lack of assessment of the state of the body, omitting questions about consent to institutional treatment, making treatment dependent on age (older people is the most medically neglected group (Derejczyk, 2000). According to modern gerontological knowledge, no one is ill just because they are old, but because they suffer from a specific disease that can be diagnosed and treated (Caird \& Judge, 1984).

Apart from the refusal to perform a medical procedure due to age, an example of institutional ageism is, for example, the actual necessity to stop working after reaching retirement age. We encounter the age discrimination phenomenon on the labor market when due to age, an employee is - or could be - treated less favorably than other employees in a comparable 
situation. Manifestations of discrimination against older people in the labor market may be related, for example, in the recruitment process to statements in advertisements, such as "we offer a job in a young, dynamic team", a "young person welcome" (indirectly), or containing a clear age limit "up to 30 years of age" (directly) - in general ignoring older workers in employment. Other signs of discrimination against older staff members may take the form of limiting access to training, courses, promotion (e.g., less frequent sending of employees to courses raising qualifications due to approaching retirement age), or forcing them to leave work due to their (retirement) age, or even dismissal from work after reaching retirement age (making way for young people).

In situations where an older person is denied the possibility of an installment purchase or a credit card because of his/her age, or in the case of the reference to young age in job advertisements - the question arises whether it is ageism or the requirements of the economy. In this context, it can also be added that sometimes 35-40 years is an unwritten turning point of "inadequate, "non-market" age. Sometimes these are deliberate, intentional actions, but sometimes they arise from a misunderstanding of the needs of seniors, e.g., small fonts in official letters, newspapers, information, too high stairs, maladjusted rooms, and the lack of chairs in the waiting rooms of offices or other public places, the need to use a computer to deal with official matters.

\section{The Legal Aspect of Age Discrimination}

The law prohibits discrimination. There are specific acts issued at different levels of government that refer to this phenomenon. In this respect, drawing on the achievements of the United Nations and the Council of Europe - in the Treaty of Amsterdam (signed in 1997), the European Union introduced Article 13 into Part I of the Treaty Establishing the European Communities (Principles), which creates opportunities for Community action aimed at combating discrimination. According to it, the Community may take the necessary measures to combat discrimination based on sex, race, ethnic origin, religion, beliefs, disability, age, or sexual orientation. In order to implement the provisions of Art. 13, the European Union adopted two directives proposing minimum standards of legal protection against discrimination in the $\mathrm{EU}$ (constituting a kind of anti-discrimination framework, generally relating to access to employment, goods, and services):

- Council Directive 2000/43/EC of 29 June 2000 implementing the principle of equal treatment between persons irrespective of racial or ethnic origin (Official Journal of the European Communities L 180 of 19.07.2000);

- Council Directive 2000/78/EC of 27 November 2000 establishing a general framework for equal treatment in employment and occupation (Official Journal of the European Communities L 303 of 2.12.2000) obliging the Member States to develop and implement national legal regulations to eliminate discrimination in employment and occupation; 
- The Community Action Programme to Combat Discrimination (2001-2006) (Podsiadło-Dacewicz, 2005, p. 114).

Also, Art. $21 \S 1$ of the Charter of Fundamental Rights of the European Union of 2009 prohibits discrimination based on age, sex, race, skin color, etc. (Official Journal of the European Union 2012/C 326, no. C 326/391).

Art. 32 point 2 of the Constitution of the Republic of Poland (Konstytucja RP, 1997) prohibits discrimination in political, social or economic life "for any reason whatsoever". The Labor Code (26.06.1974) states that any discrimination in employment, direct or indirect, in particular in respect of gender, age, disability, race, religion, nationality, political views, trade union membership, ethnic origin, creed, sexual orientation, or in respect of the conditions of employment for a definite or an indefinite period or full or part-time, are prohibited.

In general, the approach in the EU law is more general. Any form of age discrimination is prohibited; on the other hand, the national law - the Polish Labor Code - presents a more casuistic approach, i.e., it clarifies the areas in which discrimination may occur (it may happen) and in which it is prohibited, i.e., access to employment, job selection, access to training courses (Butrymowicz, 2010).

\section{Results of Research on Age Discrimination}

It can be concluded that age discrimination functions in social consciousness and attitudes. Sometimes, its manifestations are difficult to notice at first glance, but they are identified and described in the literature more and more often (Nicole-Urbanowicz, 2006; RaszejaOssowska, 2017). In recent years, several studies on (the perception of) age discrimination have also been conducted, in which both younger and older people were asked about it. For example, the Eurobarometer survey shows that in 2008, 34\% of Poles assessed age discrimination as a common problem (Discrimination in UE, 2008). In turn, in Diagnoza społeczna $2009,0.9 \%$ of people aged $60-64$ and $0.4 \%$ of people aged 65 and over declared that they had experienced discrimination (Czapiński \& Panek, 2009, p. 328). In-depth research on discrimination against older people in Poland was carried out in 2005 in eight Polish cities (people aged 50+ were inquired) (Tokarz, 2005). Moreover, in 2016, both a representative sample of adult Poles and seniors themselves were asked about worse treatment in the CBOS survey (CBOS, 2016b). In the meantime, research was conducted, which resulted in the preparation of studies on discrimination against older people in health care (Kropińska, 2013; Burak \& Rzeczyńska, 2015; Jędrzejkiewicz, Dobrowolska, and Kaučič, 2015). For example, according to Sylwia Kropińska's findings, the state of health, financial situation, and macroeconomic conditions of older people impact ageism in health care. Another area that attracts the attention of researchers is the labor market, where manifestations of discrimination are also identified (Butrymowicz,2018; Gajowiak, 2017). Research is also conducted to develop various tools used to assess social attitudes toward aging people - including worse treatment due to age (Strugała et al., 2013). 


\section{Goals and Methods of the Own Research}

The main goal of the research was to identify the term age discrimination and its manifestations toward older people. The research was intended to help answer the following questions: do older people perceive age discrimination, and have they experienced discriminatory treatment because of age? It was also important to ascertain how many surveyed seniors experienced worse treatment and what forms it most often took. The seniors were also asked what they associate old age with and when (subjectively according to the respondents) it begins.

The research theses predicted, among others, that active seniors perceive some signs of age discrimination, but this is not a common problem for them; older people witness age discrimination more often than they experience it themselves; more advanced age, material conditions, and worse state of health conduce to experiencing worse treatment due to age.

\section{Characteristics of the Surveyed Group and Results}

The purposive sampling technique ${ }^{1}$ was used to choose the research sample - the assumption was to examine active older people related to a large city who get involved and participate in various activities and projects carried out by non-governmental organizations. The study was conducted in Gdańsk, which is one of the leaders in the country in terms of the implemented urban senior policy - similarly to nearby Sopot and Gdynia, where the authorities, with the participation of third sector organizations operating in this area, are involved in many initiatives and projects concerning older people (Kubiak, 2016; 2017), moreover, there are seniors' councils in each of these cities (Kubiak 2018).

The method of a diagnostic survey with a questionnaire, which included both closed and open-ended questions, was used in the research. The questions concerned, among others, associations with old age and the chronological location of its beginning (calendar age). If the seniors answered some closed questions affirmatively, they were asked for the description and clarification.

1 Purposive sampling consists in selecting for research those individuals, social groups that meet certain criteria and are characterised by certain properties desired by the researcher. In this selection, the researcher does not rely on a coincidence and does not qualify every individual for research, but is guided by the knowledge he/she has about the population of interest, its specific features and properties, and the goal of the conducted research. The purposive sampling technique is used when the research is based on small populations, or when we want to examine certain specific features or properties of individuals (e.g., extremely gifted and successful people, socially maladjusted people, coming from pathological families, individuals deviating from typical behaviour and standards of conduct, leaders of a movement or persons with a specific political, religious, social orientation, etc.). Sometimes purposive sampling adopts extreme criteria: the best or the worst (e.g., selection of the representation of students in sports, in subject contests). 
The research was carried out on 8.01-10.03.2020 in Gdańsk, 70 people, that is 55 women (78.5\%), and 15 men (21.5\%) took part in it $^{2}$. The youngest surveyed person was 63 years old, the oldest 90 . The greatest number of people taking part in the study came from the younger age group of seniors (up to 74 years of age), and there were 15 people from the older age group (75-90). The average age of the surveyed older people was 71.5 years. More than half of the respondents had secondary education (38 people), followed by people with higher education (20 people $)^{3}$, vocational (11 people), and one person (1) with primary education. People with secondary and higher education were overrepresented in the study. However, taking into account the subject and specificity of the examined problem, it seems to be an advantage as it is assumed that the higher the level of education of older people, the more they are aware of the symptoms of discriminatory treatment (and are more sensitive to it) and of their rights. Additionally, the overrepresentation of people with higher and secondary education, as well as social and physical activity of a large part of the respondents, lead to the conclusion that they have good cognitive competences and are more sensitive to the manifestations of the studied problem (Tokarz, 2005, p. 91).

The vast majority of the respondents ( 55 people) were residents of a large city - Gdańsk, another 12 people lived in a medium-sized urban center, 2 people came from a small town, and 1 person lived in the country. Regarding marital status, the numbers of married people (28) and widows/widowers (31) were almost equal, 9 people were divorced, and 2 were unmarried. It can be added that most of the respondents (42) lived alone.

In terms of the state of health, almost half of the respondents subjectively described it as "very good" (3 people) and "good" (30 people), while 36 people as "so-so", and 1 person - as "bad"4. When the survey was being carried out, a vast majority of the respondents were retired, 7 persons worked - sporadically (5), or had a full-time job (2). Thus, in general, only every tenth person did work in any form.

As far as the level of monthly net income per person is concerned, it can be said that the middle ones dominated among the eight separate ranges. Thus, almost every fourth person had from PLN 1,500 to 2,000 at their disposal (18 people) and the same number of people from PLN 2001 to 2,500 (18 people), 15 people placed their income in the range of

2 The structure of the population of older people ( 65 and over) by gender in Poland: women $60.4 \%$, men 39.6\% (GUS, 2020, p. 163). In the own research (purposive sampling of active seniors) the ratio of women (overrepresentation) to men shows the low share and level of interest of men in various forms of initiatives and activities for older people.

3 The share of people with secondary and higher education in the study is about twice as high as for the general population in Poland - nationwide the structure of the education level of older people: higher approx. 13\%, secondary approx. 29\%, vocational approx. 33\%, primary 25\% (CBOS, 2016a, p. 5).

${ }^{4}$ In a nationwide survey in 2018, $1.9 \%$ of people aged 60 and over assessed the state of their health as "very good", 23.8\% - "good", $47.3 \%$ as "so so","neither good nor bad", $21.1 \%$ as "bad" and 5,9\% as "very bad", GUS, 2020a, p. 53. 
PLN 2,501-3,000. In total, over half of the respondents (37 people) had an income above PLN 2,000, but 15 people had a sum of no more than PLN 1,500 per month (the detailed distribution of the respondents' income is presented in Table 1). Overall, the financial situation was (subjectively) described by more than half of the respondents as "good" (38 people) or "so-so" (30 people), and in 2 cases, even as "very good" (no one assessed their financial situation as "bad").

Table 1. Synthetic characteristics of the respondents

\begin{tabular}{|c|c|c|}
\hline & & $\begin{array}{l}\text { number of } \\
\text { people }\end{array}$ \\
\hline \multirow[t]{2}{*}{ Sex } & Women & 55 \\
\hline & Men & 15 \\
\hline \multirow[t]{4}{*}{ Education } & higher & 20 \\
\hline & secondary & 38 \\
\hline & vocational & 11 \\
\hline & primary & 1 \\
\hline \multirow[t]{2}{*}{ Age range } & $60-74$ years & 55 \\
\hline & $75-90$ years & 15 \\
\hline \multirow[t]{4}{*}{ Place of residence } & town +100 thousand residents & 55 \\
\hline & town $20-100$ thousand residents & 12 \\
\hline & town up to 20 thousand residents & 2 \\
\hline & countryside & 1 \\
\hline \multirow[t]{4}{*}{ Marital status } & widow/widower & 31 \\
\hline & married & 28 \\
\hline & divorced & 9 \\
\hline & unmarried & 2 \\
\hline \multirow[t]{4}{*}{ State of health } & very good & 3 \\
\hline & good & 30 \\
\hline & so so & 36 \\
\hline & bad & 1 \\
\hline \multirow[t]{3}{*}{ Current employment status } & retired & 63 \\
\hline & working sporadically & 5 \\
\hline & full-time job & 2 \\
\hline \multirow[t]{8}{*}{ Income level } & up to PLN 1000 & 2 \\
\hline & PLN $1001-1500$ & 13 \\
\hline & PLN 1501-2000 & 18 \\
\hline & PLN 2001-2500 & 18 \\
\hline & PLN 2501-3000 & 15 \\
\hline & PLN 3001-3500 & 1 \\
\hline & PLN 3501-4000 & 2 \\
\hline & PLN 4001-4500 & 1 \\
\hline \multirow[t]{4}{*}{ Financial situation } & very good & 2 \\
\hline & good & 38 \\
\hline & so so & 30 \\
\hline & bad & - \\
\hline
\end{tabular}

Source: own study. 
The first question was open-ended and concerned associations with old age (I associate old age primarily with...). All the answers given by older people (66) were analyzed and organized into seven categories (Table 2). The relatively highest number of people - almost half (32) associated old age with mobility problems, diseases, and physical limitations. Every $5^{\text {th }}$ person (14 people) identified old age with free time and rest, while only 2 with experience. Subsequent responses linked old age with declining years (6 people), and the same number of answers, i.e., 4 answers each with retirement, loneliness, and passing, respectively. Accordingly, it is quite clear that there was a rather negative attitude toward old age among the respondents.

Table 2. Old age - associations

\begin{tabular}{lc}
\hline & number of people \\
\hline disability, physical limitations & 32 \\
\hline free time, rest & 14 \\
\hline declining years & 6 \\
\hline loneliness & 4 \\
\hline retirement & 4 \\
\hline the passing of time & 4 \\
\hline experience & 2 \\
\hline no answer & 4 \\
\hline
\end{tabular}

Source: own study.

The next (controversial) question was related to the onset of old age (the age at which you consider a person old). 67 people answered it, and interestingly, more than half (37) pointed to 80 as the beginning of old age, 9 people chose 70 years. Slightly fewer, because 8 people indicated 90 years of age, while the same number, i.e., 6 people, placed the beginning of old age at 85 and 75 years, respectively (for 1 person, old age begins only when they turn 100 years of age) (Table 3 ). When we take into account the arithmetic mean calculated for the respondents' subjective opinion on the beginning of old age, which was almost 80 years (79.85 years) and recall at this point that the average age of the respondents was 71.5 years, it turns out that the vast majority believed (during the study) that they would only reach the threshold of calendar old age in a few years.

Table 3. The onset of old age according to the respondents

\begin{tabular}{lc}
\hline Onset of old age (years of age) & number of people \\
\hline 80 years of age & 37 \\
\hline 70 years of age & 9 \\
\hline 90 years of age & 8 \\
\hline 85 years of age & 6 \\
\hline 75 years of age & 6 \\
\hline 100 & 1 \\
\hline no answer & 2 \\
\hline
\end{tabular}

Source: own study. 
The subsequent question was whether, in the respondents' opinion, belonging to the group of older people is the reason for worse treatment. In this regard, practically every fourth person (16) answered yes, almost half of them denied (32 people), and 22 people did not have an opinion.

Table 4. Old age and worse treatment

\begin{tabular}{lllll}
\hline & yes & no & \multicolumn{2}{l}{$\begin{array}{l}\text { difficult to } \\
\text { say }\end{array}$} \\
\hline Being an older person is the reason for worse treatment & 16 & 32 & 22 & 70 \\
\hline Are older people in Poland treated badly/worse? & 18 & 22 & 30 & 70 \\
\hline $\begin{array}{l}\text { Are older people in Poland discriminated against on the grounds } \\
\text { of age? }\end{array}$ & 18 & 21 & 31 & 70 \\
\hline
\end{tabular}

Source: own study.

Answers to whether older people in Poland are treated badly/worse and if they are discriminated against on the grounds of age were similarly distributed. Just over 1/4 (18 people) answered affirmatively, while about $1 / 3$ denied. In turn, for 30-31 people, it was difficult to identify the problem (detailed data are presented in Table 4). Generally, as a result of the analysis of the results, it can be concluded that seniors equate bad or worse treatment of older people with age discrimination.

A natural consequence of the scientific inquiries was an (open) question to which the respondents replied by writing how they understand age discrimination (what associations it evokes).

Table 5. Age discrimination (understanding/associations)

\begin{tabular}{lc}
\hline list of answers & number of people \\
\hline ignoring needs, disregarding & 16 \\
\hline no medical examination at a certain age & 10 \\
\hline worse/bad treatment & 9 \\
\hline compulsory retirement & 7 \\
\hline offensive words & 2 \\
\hline at this age it is not appropriate & 2 \\
\hline no answer & 24 \\
\hline
\end{tabular}

Source: own study.

The answers of the seniors (who entered the answer) were analyzed and sorted into six categories. Therefore, it can be concluded that the relatively highest number of people associate age discrimination with ignoring needs and disregard (16 people), followed by answers related to the lack of medical tests at a certain age (10 people) and generally worse/ poor treatment ( 9 people), or compulsory retirement (7 people). Answers such as: "offensive words" (2 people) or "it is not appropriate at this age" (2 people) seldom appeared. 
Table 6. Perception of worse treatment due to age

\begin{tabular}{lcccc}
\hline & yes & no & $\begin{array}{l}\text { difficult } \\
\text { to say }\end{array}$ & $\begin{array}{l}\text { no } \\
\text { answer }\end{array}$ \\
\hline I have suffered worse treatment because of my age & 15 & 49 & 6 & \\
\hline I have witnessed discrimination against another older person & 20 & 44 & 6 & - \\
\hline I have met with verbal aggression & 14 & 49 & 7 & - \\
\hline I have witnessed verbal aggression toward another older person & 24 & 42 & 3 & 1 \\
\hline My words have been disregarded & 13 & 43 & 14 & - \\
\hline I have witnessed disregard for words of another older person & 23 & 33 & 13 & 1 \\
\hline $\begin{array}{l}\text { Has a doctor ever told you that the reason for ailments is your age } \\
\text { or old age? }\end{array}$ & 49 & 21 & - & - \\
\hline Do seniors in Poland have limited access to medical services? & 32 & 16 & 22 & - \\
\hline Is age discrimination a social problem? & 25 & 15 & 30 & - \\
\hline
\end{tabular}

Source: own study.

The vast majority of answers to whether the respondents have ever suffered worse treatment because of their age were negative ( 49 people). However, some people, i.e., 15, had experienced it, while for several of them (6 persons), it was difficult to identify such a phenomenon. The analysis of the research material showed that those older people who had experienced ill-treatment due to their age had also encountered (witnessed) worse treatment of other seniors. A closer examination of the profiles of people who said they had experienced worse treatment due to age showed that they were aged 68-72, almost exclusively women (only 1 man), with a "so-so" state of health, saying (overall) that older people are treated worse. $2 / 3$ of them also witnessed discrimination against another older person, and $3 / 4$ of them stated that age discrimination was a social problem. $2 / 3$ of them had also witnessed discrimination against another older person, and 3/4 of them stated that age discrimination was a social problem. It can be added that practically all (except 1 person) had heard from a doctor that their ailments were caused by old age.

At the next stage, the responses of those who felt badly treated (due to their age) and identified the circumstances of this event were analyzed and organized into six categories. Thus, it most often took place in the following order: in a health center (6 people), in the street (2), in a shop (2), in means of transport (2), and 1 person each at a workplace and in a public office. It can be added that 14 people offered the answer and clarified it in terms of place, and 56 people ignored this point.

Twenty people had witnessed discrimination against another older person. A vast majority (44 people) had not noticed such a phenomenon, while 6 respondents found it difficult to say. Overall, seniors had witnessed age discrimination a little more often than they had experienced it themselves. As in the previous case - when it comes to places where the respondents observed discrimination against another older person, also here they most often identified this phenomenon in means of transport ( 6 people), in health centers ( 5 people), 
but also in public offices/banks (4 people) and the workplace ( 3 people), in a shop ( 2 people) (50 people did not answer this question).

In the context of verbal aggression, sometimes considered a sign of bad treatment, every $5^{\text {th }}$ older person had experienced it personally, and for every tenth person, it was difficult to say. Not all who had encountered this phenomenon concerning themselves (14 people) described the circumstances of the incident, but among 12 people it had been most often experienced in public transport ( 5 people), in a shop (4), while 3 people replied that these were teenagers' comments (as a reaction to admonishing them). As in the case of the question related to worse treatment, also in the matter of verbal aggression, the surveyed seniors had more often witnessed it than experienced it themselves. In reply to the question about witnessing verbal aggression toward another older person, every third (24) replied in the affirmative, although a vast majority ( 42 people) had not identified such a phenomenon so far. More detailed answers about the circumstances of noticing verbal aggression toward another older person were given by 19 persons, and it had most often happened in means of transport (12), a shop (6), and a public office (1).

Almost every fifth person (13) among the respondents stated that they had experienced disregard for what they said, a similar number (14 people) had difficulty answering this question, and 43 people stated that they had not encountered disregard for their words. If the words spoken by the surveyed seniors had been disregarded, such a situation had most commonly occurred during social conversations, in a health center, and a public office. Here it can also be emphasized that, as in the case of worse treatment and verbal aggression, seniors had more often witnessed disregard for the words of another older person than experienced it themselves. Out of 69 people who answered this question, 1/3 (23 people) answered affirmatively, 33 people had not met it, and for 13 people, it was difficult to say. Some people who had witnessed disregard for words of another older person (19 people) indicated means of transport ( 9 people), a shop/market (5), family (4), and public office (1) as places/circumstances where it had happened.

The distribution of answers to whether a doctor has ever told the respondent that the cause of his/her ailments are age and/or old age was very interesting. In this regard, 49 people (i.e., over $2 / 3$ of the respondents) confirmed such behavior of the doctor, while $1 / 3 \mathrm{had}$ not encountered anything like that.

Another question was whether seniors in Poland have limited access to medical services. In this matter, nearly half ( 32 people) answered yes, for 22 people, it was difficult to say, while 16 respondents did not see such a problem. However, the reasons were the most important, that is why the seniors themselves think so. The open-ended question about this issue received 30 answers, which were analyzed and arranged into categories (Table 7). In the first place in terms of the problem of poor access to medical services, there was a cluster of reasons, namely: long waiting periods, queues, too long waiting time for appointments with specialists (19 people), the next - no referrals for preventive examinations explained 
by age ( 5 people), 4 people stated that in medical centers it is clear that older people are unwelcome, 2 people indicated the lack of geriatricians.

Table 7. The reasons for the limited access of seniors to medical services according to the respondents

\begin{tabular}{ll}
\hline Limited access to medical services & “yes" 30 people \\
\hline long waiting periods, queues, too long waiting time for appointments with specialists & 19 \\
\hline no referrals for preventive examinations explained by age & 5 \\
\hline in medical centers it is clear that older people are unwelcome & 4 \\
\hline lack of geriatricians & 2 \\
\hline
\end{tabular}

Source: own study.

For 25 people (almost 1/3) of the respondents, age discrimination turns out to be a social problem, 30 people found it difficult to acknowledge such a state of affairs, while 15 people denied it. Seniors who claimed that discrimination is a social problem most often gave (20) the following answers as the reason for such a state of affairs: the lack of respect of the young for older people/the issue of upbringing ( 9 people), social welfare deficit/high prices of nursing homes (4), age limit for some health tests and campaigns (4), the potential of older people is not used (1), the term senior is used in access to something (1), older people are disregarded (1).

Subsequently, the seniors also identified the main areas where they believe age discrimination takes place. Twenty-six people provided answers (44 did not), and the largest number of them (12 people) pointed to health care as a controversial area in this respect, followed by the areas of employment (7), public transport (4), public offices/banks (3 people).

More than half - 36 people answered the question about the reasons of age discrimination (Table 8) - their answers were analyzed and arranged. The greatest number of them - more than half - 20 people recognized bad manners and the lack of respect and education as the causes of discrimination, 1/4 considered physical awkwardness, lack of efficiency, and optimism, while 7 people said that the most important reasons resulted from the perpetuation of stereotypes and little knowledge about old age.

Table 8. Reasons of age discrimination

\begin{tabular}{lc}
\hline Reason/s & $\begin{array}{l}\text { Number of } \\
\text { people }\end{array}$ \\
\hline bad manners, lack of respect and education & 20 \\
\hline physical awkwardness /old age/ lack of efficiency/lack of optimism & 9 \\
\hline perpetuation of stereotypes/little knowledge about old age & 7 \\
\hline no answer & 34 \\
\hline in total & 70 \\
\hline
\end{tabular}

Source: own study. 
The answer to the question about organizations working for equal treatment and counteracting discrimination (including on the grounds of age) was important from the point of view of the place where the study was carried out and the seniors themselves (the vast majority of them active). The point was to find out if the respondents know (are aware of) organizations/institutions that deal with and help with problems related to unequal treatment. The question was particularly important because of the establishment of the Gdańsk Equal Treatment Centre (GETC) $)^{5}$ in 2019 and the effects of its operation ${ }^{6}$. While about a quarter of the respondents gave an affirmative answer in this matter, i.e., they were conscious of the existence of some anti-discrimination organizations (14 people had difficulties with this, and more than half of them had never heard of them), the identification of specific ones was much more difficult.

Table 9. Organizations and the need to conduct anti-discrimination activities

\begin{tabular}{lcccc}
\hline & yes & no & $\begin{array}{c}\text { difficult } \\
\text { to say }\end{array}$ & $\begin{array}{l}\text { no } \\
\text { answer }\end{array}$ \\
\hline $\begin{array}{l}\text { Do you know organizations working for equal treatment and prevent- } \\
\text { ing age discrimination? }\end{array}$ & 18 & 38 & 14 & - \\
\hline $\begin{array}{l}\text { Have you ever participated in a lecture or workshop on age discrimina- } \\
\text { tion? }\end{array}$ & 11 & 53 & 6 & - \\
\hline Should age anti-discrimination activities be conducted? & 40 & 4 & - & 26 \\
\hline
\end{tabular}

Source: own study.

5 The GETC was created in Gdańsk on 15.04.2019 as a network of 7 cooperating non-governmental organisations and units of the City of Gdańsk, whose aim is to provide support to people experiencing discrimination. It was established in order to implement the pilot public task Dissemination and Protection of Freedom and Human Rights, commissioned by the City Hall in Gdańsk (in 2020 the project was extended until December 2022). It is the implementation of one of the most important recommendations of the Gdańsk Model for Equal Treatment adopted in June 2018. One of the goals of the GETC is the creation and operation in the network of points supporting people experiencing discrimination and violence on the grounds of age, gender, sexual orientation and gender identity, disability, denomination, religion and lack of religious denomination, ethnic and national origin, including keeping a register and monitoring manifestations of discrimination. According to the survey commissioned by the GETC, age discrimination was experienced personally by $3.1 \%$ of the respondents in 2017, while in $20194.1 \%$, when asked if the respondents knew someone who had experienced age discrimination, $4.8 \%$ of respondents from Gdańsk responded affirmatively (GETC, 2019, pp. 23-28).

6 Among 152 people who used the GETC services in the period from May to December 2019, 2 people were qualified for individual support as discriminated against on the grounds of age (the cases concerned difficulties with contacts with officials and harassment by neighbours), the largest number of people were qualified for support as a result of their gender, psychosexual orientation and disability/ state of health. In total, 749 hours of support and 18 support groups were provided - 113 hours of group support (GETC, 2019, p. 17). 
7 people in total mentioned an existing entity: (only) 3 people mentioned the WAGA association (a member organization of the GETC network), 2 people entered the Gdańsk Equal Treatment Centre (small recognition of the GCRT activities may be related to its short operation - April-December 2019), and 1 person replied that such matters are dealt with by the Commissioner for Human Rights and one person also mentioned the Polish AntiDiscrimination Law Association. It must be said that this is a fairly low level of identification of activities of such organizations and is all the more puzzling as 11 people from among the respondents had participated in a workshop or lecture on age discrimination. On the other hand, most of the respondents -40 people agreed that age anti-discrimination activities should be carried out (only 4 people were of the opposite opinion, and 26 people ignored this question).

\section{Conclusions}

The analysis of the research material showed that the surveyed seniors most often associate old age negatively (with diseases, physical limitations, loneliness, passing). The onset of old age was estimated at almost 80 years (with the average age of the respondents being 71.5 years). Only a quarter of people said that belonging to the group of older people was the reason for worse treatment. The relatively largest number of older people associate age discrimination with ignoring needs and disrespect, with the lack of medical examinations at a certain age, general ill-treatment, or compulsory retirement. The vast majority of seniors did not experience any manifestations of worse treatment; in turn, 15 people identified them. Those who felt worse treated due to their older age most often experienced it in the following order: in a health center, the street, a shop, means of transport, a workplace, and a public office. It should be emphasized that seniors witnessed age discrimination slightly more often than they experienced it themselves. Similar conclusions can be drawn when it comes to verbal aggression. It is disturbing that as many as $2 / 3$ of the surveyed people confirmed that a doctor once told them personally that the cause of their ailments was their age and/or old age. Nearly half of the respondents also replied that seniors in Poland have limited access to medical services, and the most important reasons for this state of affairs were: long waiting periods, queues, no referrals for preventive examinations explained by age. For almost $1 / 3$ of the surveyed people, age discrimination turns out to be a significant social problem, and the reasons for this state of affairs include, among others: the lack of respect of the young for older people/bad manners, social welfare deficit, the age limit for some medical tests and health actions. The main places of age discrimination turned out to be: health protection, employment, public transport, public offices/banks. Despite the relatively low level of recognition of institutions and organizations involved in anti-discrimination activities (also on the grounds of age), more than half of them agreed that they should be conducted. They are one of the directions of the senior policy that affects the quality of life of older people, both at the local and central levels of the state. It is important here to shape 
models of culture toward older people - building a positive image without bias, stereotypes, and discrimination, promoting good practices and engaging seniors in various types of activities - primarily at the local level.

\section{References:}

GECT. (2019). Badanie ewaluacyjne Gdańskiego Centrum Równego Traktowania. Raport końcowy. https:// gcrt.pl/raport-koncowy-badanie-ewaluacyjne-cgrt,13,pl

Burak,A., \& Reczyńska,A. (2015). Dyskryminacja pacjentów w starszym wieku przez pracowników ochrony zdrowia. Geriatria, 9, 218-226.

Butler, R.N. (1969). Age-ism: Another form of bigotry. The Gerontologist, 9(4), 243-246.

Butler, R.N. (1975). Why survive? Being in old in America. Harper \& Row.

Butymowicz, M. (2018). Dyskryminacja w dostępie do pracy ze względu na wiek - osoba starsza w pracy. Studia Socialia Cracoviensia, 10,1(18), 103-114.

Bytheway, B. (1995). Ageism. Open University Press.

Caird, F.I., \& Judge, T.G. (1984). Badanie kliniczne w geriatrii. PZWL.

CBOS. (2016a). Portret społeczno-demograficzny seniorów. Komunikat z badań CBOS. 160. https://www. cbos.pl/SPISKOM.POL/2016/K_160_16.PDF.

CBOS. (2016b). Czy osoby starsze są w naszym społeczeństwie dyskryminowane? Komunikat z Badań CBOS 164. https://www.cbos.pl/SPISKOM.POL/2016/K_164_16.PDF

Cieślikowska, D. (2010). Dyskryminacja. In M. Branka, \& D. Cieślikowska (Eds.), Edukacja antydyskryminacyjna. Podręcznik trenerski (pp. 66-74). Villa Decius.

Czapiński, J., \& Panek, T. (2015). Diagnoza społeczna. Warunki i jakość życia Polaków. Rada Monitoringu Społecznego.

Derejczyk, J. (2000). Geriatria a reforma ochrony zdrowia w Polsce. Stużba Zdrowia, 27(61-64), 2954-2957.

Discrimination in the European Union. (2008). Special Eurobarometer 296 Report, Wave 69.1 - opinion and social.

Dubanik, J., \& Kubacka. J. (2010). Ageizm, In M. Branka, \& D. Cieślikowska (Eds.),Edukacja antydyskryminacyjna. Podręcznik trenerski (pp. 136-143). Villa Decius.

Gajowiak, M. (2017). Dyskryminacja ze względu na wiek - wybrane aspekty. Zeszyty Naukowe Politechniki Poznańskiej. Organizacja i Zarzadzanie, 73, 63-79. DOI: 10.21008/j.0239-9415.2017.073.05

GUS. (2019). Ludność. Stan i struktura oraz ruch naturalny w przekroju terytorialnym $w 2018 \mathrm{r}$. https:// stat.gov.pl/obszary-tematyczne/ludnosc/ludnosc/ludnosc-stan-i-struktura-oraz-ruch-naturalny-wprzekroju-terytorialnym-w-2018-r-stan-w-dniu-31-xii,6,25.html

GUS. (2020a). Sytuacja osób starszych w Polsce w 2018 r. https://stat.gov.pl/obszary-tematyczne/osobystarsze/osoby-starsze/sytuacja-osob-starszych-w-polsce-w-2018-roku,2,1.html

GUS. (2020b). Jakość życia osób starszych w Polsce. https://stat.gov.pl/download/gfx/portalinformacyjny/ pl/defaultaktualnosci/5486/26/2/1/jakosc_zycia_osob_starszych_w_polsce.pdf

Herman, A. (2017). Przeciwdziałanie zjawisku ageizmu na przykładzie miasta Lublin. Annales Universitatis Mariae Curie-Skłodowska Lublin - Polonia, sectio J, vol. XXX(4), 159-167. http://dx.doi. org/10.17951/j.2017.30.4.159

Jędrzejkiewicz, B., Dobrowolska, B., and Kaučič, B.M. (2015). Wybrane aspekty opieki geriatrycznej w opinii osób starszych oraz studentów medycyny i pielęgniarstwa w kontekście dyskusji na temat ageizmu w sektorze opieki zdrowotnej. Gerontologia Polska, 4, 165-171. 
Kilian, M. (2004). Źródła ageizmu i jego przejawy we współczesnym świecie. Gerontologia Polska, 12(3), $125-128$.

Konstytucja Rzeczypospolitej Polskiej. (1997).2.04. Dz.U. z 1997 nr 78 poz. 483.

Kropińska, S. (2013). Dyskryminacja osób starszych ze względu na wiek w polskim systemie ochrony zdrowia, (Doctoral dissertation). http://www.wbc.poznan.pl/Content/298683/index.pdf

Kubiak, M. (2016). .Polityka senioralna w Gdańsku - przykłady lokalnych inicjatyw. In J. Ayleytner (Ed.), Krajowe i międzynarodowe konteksty polityki społecznej (pp. 391-409). PTPS, Wyższa Szkoła Pedagogiczna im. J. Korczaka.

Kubiak, M. (2017). Analiza porównawcza polityki senioralnej w skali lokalnej na przykładzie Gdańska, Sopotu i Gdyni. In A. Chabior, \& M. Porąbaniec (Eds.), Dylematy polityki społecznej i pracy socjalnej - implikacje dla teorii i praktyki (pp. 147-166). Uniwersytet Jana Kochanowskiego w Kielcach.

Kubiak, M. (2018). Gminne rady seniorów z perspektywy lokalnej polityki senioralnej. Wrocławskie Studia Politologiczne, 25, 101-117. DOI:10.19195/1643-0328.25.7

Mitosek, Z. (1974). Literatura i stereotypy. Zakład Narodowy im. Ossolińskich, PAN.

Moore, P., \& Conn, C.P. (1985). Disguised: A True Story. Word Books.

Nicole-Urbanowicz, J. (2006). Ageizm i dyskryminacja ze względu na wiek. Niebieska Linia, 6. https:// www.niebieskalinia.pl/pismo/wydania/dostepne-artykuly/4603-ageizm-i-dyskryminacja-ze-wzgleduna-wiek

Palmore, E., \& Manton, K. (1973). Ageism compared to racism and sexism. Journal of Gerontology, 28(6), 363-369.

Podsiadło-Dacewicz, I. (2005). Antydyskryminacja. Pakiet edukacyjny. Centralny Ośrodek Doskonalenia Nauczycieli.

Raszeja-Ossowska, I. (2017). Ageizm dyskryminacja ze względu na wiek. http://witrynawiejska.org.pl/ data/ageizm 2017.pdf

Strugała, M., Zielińska, A., Dymek-Skoczyńska, A., and Czyżewska-Torba, P. (2013). Narzędzia pomiarowe służące ocenie postaw społecznych względem osób starszych - krótka charakterystyka. Nowiny Lekarskie, 82(1), 70-75.

Tokarz, B. (2005). STOP dyskryminacji ze względu na wiek. Akademia Rozwoju Filantropii w Polsce.

Traxler, A.J.(1980). Let's get gerontologized: Developing a sensitivity to ageing. The multi-purpose senior center concept: A training manual for practitioners working with the ageing. Illinois Department of Ageing. Woźniak-Hasik, Z. (2007). Problem dyskryminacji ze względu na wiek. Mazowieckie Centrum Zdrowia Publicznego. 